\title{
Globalization and the Question of African Identity
}

\author{
Damian Ilodigwe \\ Saints Peter and Paul Major Seminary, Bodija, Ibadan and University of Ibadan, Nigeria
}

Copyright $\odot 2018$ by authors, all rights reserved. Authors agree that this article remains permanently open access under the terms of the Creative Commons Attribution License 4.0 International License

\begin{abstract}
A prominent feature of the contemporary society in the last couple of decades is the phenomenon of globalization. While globalization has brought immense benefits to Africa on the one hand, Africa's entrance into and participation in the global scene has also precipitated a crisis of confusion and identity for Africa-a situation which is analogous to the effect of her encounter with colonialism, so that unless the dialectic of identity and difference that inevitably arises from this situation is constructively managed, it will be difficult for Africa to make the best of the opportunities inherent in globalization. Given that no one can make the best of any opportunity for interaction with others unless one is clear about one's identity and priorities, a major challenge Africa has to address in the context of globalization is the need to assume personal responsibility in defining her priorities and interests such as to allow these to inform her engagement with the various participants in the global world. More often than not, the Achilles heel of Africa is lack of clear focus in respect of her priorities as well as failure to allow her interests to drive her engagement with other participants in the global system. To reverse the situation of dependency which this mode of operation fosters, we argue that, Africa not only needs to relocate her locus of control internally and put in place a strong regime of internal democracy based on rule of law to tackle the menace of corruption and mismanagement that have undermined development initiatives since independence, but more importantly Africa needs to be allowed to assert itself by ensuring certain equity, justice and balance in the inner workings of the International System so that the environment is enabling and not paralyzing as far as the operation of various stakeholders within the system is concerned especially African countries.
\end{abstract}

Keywords Globalization, Identity, Development, Democracy, Imperialism and Neo-colonialism

\section{Preamble}

A prominent feature of the contemporary society in the last couple of decades is the phenomenon of globalization.
Because of the pragmatic success of modern science in revolutionizing the human condition, it is easier now more than ever for peoples and nations to interact closely without having to transverse any physical space. The result is the emergence of a global society with immense opportunities for social, economic and political intercourse, so that it is virtually impossible to operate in isolation in the global society without being affected by state of affairs in the system.

Our contention in this paper is that while globalization has brought immense benefits to Africa on the one hand, Africa's entrance into and participation in the global scene has also precipitated a crisis of confusion and identity for Africa-a situation which is analogous to the effect of her encounter with colonialism, so that unless the dialectic of identity and difference that inevitably arises from this situation is constructively managed, it will be difficult for Africa to make the best of the opportunities inherent in globalization.

Given that no one can make the best of any opportunity for interaction with others unless one is clear about one's identity and priorities, a major challenge Africa has to address in the context of globalization is the need to assume personal responsibility in defining her priorities and interests such as to allow these to inform her engagement with the various participants in the global world. To do this effectively requires a sustained processing of her past experience such as to allow the lessons of the past to constitute the foundation for her self-understanding of her current situation as well as her future operations in the global world.[1]

More often than not, the Achilles heel of Africa is lack of clear focus in respect of her priorities as well as failure to allow her interests to drive her engagement with other participants in the global system. To reverse the situation of dependency which this mode of operation fosters, we argue that, Africa needs to relocate the locus of control internally. In other words she needs to take a step back and look inward rather than merely outward, so as to understand and sort out her crisis situation.[2]

Indeed the crucial burden is to clarify and refocus her interests and priorities, so that she does not persist in repeating the past mistake of failing to engage with her predicament critically and pragmatically. In this context 
one fundamental area of attention is need to put in place strong structures and democratic institutions predicated on the ideal of rule of law; for, if attention shifts from over-emphasis on strong individuals to vibrant internal democracy, Africa will re-assume control of her destiny and this is sure to enhance her capacity to participate effectively in the global scene and turn the opportunities of globalization to her advantage. Crisis is always a blessing in disguise if its hidden treasures are properly understood and well utilized. If Africa would locate her locus of control internally and allow her priorities to legislate her actions and operations in the global world her crisis of confusion and identity in the face globalization will become an occasion for self-discovery and renewal of commitment to the pursuit of excellence internally and externally.[3]

For sake of convenient exposition we develop our argument in terms of the following procedure. After an exploration of the concept of globalization and its various dimensions, we interrogate the impact of globalization on Africa by considering its benefits and liabilities but especially how it precipitates a crisis of confusion and identity for Africa and what this means for Africa's ability to participate effectively in the global scene. Thereafter we examine how the institution of a strong tradition of internal democracy can help to overcome the cycle of dependency that often results from a merely external locus of control. While we recognize the challenges that the neo-colonial trappings of globalization constitutes, the final step of our reflection suggests there is hope for Africa with respect to making the best of the opportunities of globalization, so long as she assumes responsibility in conducting her affairs internally and externally in terms of her interests and priorities. Let us begin then by focusing attention on the concept of globalization and its various dimensions.

\section{The Concept of Globalization and the Question of Its Credentials}

Commentators are in agreement with respect to the difficulties associated with defining the concept of globalization.[4] Because the term is often used in different contexts and sometimes can evoke conflicting sentiments and ideologies, it is difficult to find one definition that adequately captures its meaning.[5] Nonetheless there is the general understanding that at the heart of the concept of globalization is a certain interaction between and among various elements that make up a whole, so that when we are talking about globalization, we are talking of logic of a part and whole and the relation that subsists between them.[6]

\subsection{Global System and the Logic of Part and Whole: Question of Relation between Nations and Peoples}

Specifically, therefore, the idea is that the international system is such a whole and is made up of many countries, each with its own peoples and territory.[7] Understood as a part of a whole which relates with other parts within the whole and with the whole as a system, none of the countries that make up the international system or any other element within the international system can exist in isolation.[8] On the contrary each country or each element within the international system interacts with other countries or elements, so that none is immune from the state of affairs within the system as a whole, as one element impacts on the other elements just as the system as a whole also shapes and conditions the elements that subsist within it and their relationship.[9]

Understood in this sense, globalization refers to the process of interaction between the various elements or countries that make up the international system.[10] Because such interaction is a basic hallmark of the human nature, since, as Aristotle told us long ago in his Politics, man by nature is essentially a political animal, that must live in a society and relate with others, commentators are correct to remark that globalization is not a new phenomenon but, on the contrary, is as old as the human species, so that we can distinguish between various historical phases of the evolution of the phenomenon such as the ancient, modern and the contemporary expressions of globalization.[11]

In view of the unprecedented impact of modern science and technology on the human condition, especially since the start of the twentieth century, scholars of globalization make it a point of duty to distinguish and contrast contemporary globalization from and with earlier forms of globalization, the unique hallmark of contemporary globalization being that it involves an intensification of the process of interaction between nations and people than was the case with previous forms of globalization.[12]

This point is understandable, if we consider the myriads of discoveries and technological devices that constitute the landscape of twentieth century such as the radio, the television, the telephone, and indeed the entire revolution in the information technology like mobile phones and internet.[13] Also to be mentioned is the revolution in air travel and the communication industry with all kinds of social media that can now put people in touch with each other with just a click or tap.[14] The emergence of these technological devices implies that people can interact more closely with each other across the globe such that the international system, as it were, has been reduced to a "global village". The concept of global village serves precisely to underscore the intensification of the process of interaction between peoples and nations within the international system that is the hallmark of the phenomenon of globalization.[15]

Without prejudice to earlier expressions of globalization, it is pertinent to note that our prime focus in interrogating the question of African identity, against the backdrop of the phenomenon of globalization, is the contemporary form of 
globalization and how it has conditioned the international system. Thus when we talk of globalization in the current context of our discourse, we are refer to contemporary globalization, which represents the most sophisticated intensification of the process of interaction between nations and people that we have ever witnessed in human history.[16]

Interestingly the intensification of the process of interaction itself is a dynamic thing, so that all the time the general state of affairs in the international system is changing with new possibilities for better and closer interaction between peoples.[17] I suppose this is evident from the transition from the regime of television to the internet that has drastically revolutionized human interaction in the twentieth century and continues to do so in the twenty first.[18]

\subsection{Globalization and the Question of Its Dimensions}

Given that globalization is a form of social interaction, like all forms of social interactions it has many ramifications. Consequently by considering the various dimensions involved in the process of intensification of interaction between peoples and among nations we will gain a fuller conspectus of the nature of globalization. Commentators generally identify four dimensions of globalizations, namely, economic globalization, political globalization, cultural globalization and ecological globalization.[19] As a way of rounding off our account of the concept of globalization and its credentials before we consider how globalization impacts on African situation and identity, we will briefly look at the various dimensions of globalization and some critical issues that arise, beginning with economic globalization.

\subsubsection{The Economic Dimension of Globalization and the Question of Its Claim}

In considering the various dimensions of globalization we must note the point that the hallmark of contemporary globalization is the intensification of interaction between peoples and nations. Of course this, as we have seen, does not mean that peoples and nations have not always interacted. On the contrary it means that the interaction and the process of integration assume unprecedented sophistication in the contemporary context.[20] This is arguably true of all the dimensions of globalization especially the economic dimension of globalization. But first let us determine what is involved in the economic dimension of globalization and how it clarifies our concept of globalization.

Basically economy pertains to the production and distribution of goods and services through the means of trade and commerce. Therefore in the words of Manfred Steger, economic globalization "refers to intensification and stretching of economic interrelations across the globe."'[21] In other words, it is the "increasing economic interdependence of national economies across the world through a rapid increase in cross-border movement of goods, services, technology and capital."[22] This sort of economic interdependence through exchange of goods and services has always been a feature of human civilization in all its epochs.[23]

Nonetheless the process received a tremendous boost with the industrial revolution in the eighteenth century which stimulated international trade as Europeans sourced for raw materials abroad and established colonies to service their industries.[24] The advancement in transport and telecommunication in the nineteenth century gave further boost to the process of economic inter-dependence and integration as it meant that goods and services could be moved across borders with relative ease, so that by the start of the twentieth century there has been an unprecedented rise in the volume of international trade among nations.[25]

Commentators generally observe that the foundation of the contemporary international economic order was fashioned by the Bretton Woods Conference which took place in 1944 and had in attendance 44 nations mainly from North America, Europe and South America, including Japan and Russia under the leadership of the United States. As successor to the Hague Conference of 1893, Bretton Wood Conference sought to stabilize world currencies and establish credit for international trade in the post-World War 11 era.[26]

One of the significant achievement of the conference was the reversal of the economic policies that held sway during the interwar period by reducing tariffs on imported goods so that it had the effect of opening up national economy to foreign good and investment as opposed to the protectionism that obtained hitherto and was fostered by a deliberately high tariffs on imported good.

A second achievement of the conference in respect of laying the foundation for the current international economic system was the attempt to create "a more stable money exchange system by which the value of each country's currency was pegged to a fixed gold value of the US dollar."[27]

Thirdly, the Bretton Woods conference established several of the organizations that manage the global economy and the global financial systems such as the World Bank, the International Monetary Fund and the International Trade Organization. With the new economic order put in place by the conference, the process of the intensification of economic inter-dependence and integration that slowed down by the First World War and up till the Second World War picked up again.[28] Indeed within the last couple of decades since the end of the Second World War, the international economic order has undergone massive transformation with increasing emphasis on economic liberalization and deregulation. Significant in this respect is the General Agreement on Tariffs and Trade which was established in 1947 to fashion and implement multilateral trade agreements.[29] No less 
significant is its successor, World Trade Organization which was established in 1995. With the collapse of communism in 1989 and the demise of Soviet Union there has been a rapid development with regard to economic liberalization and economic integration.[30]

Contemporary globalization could be said to have had its best moments so far in the closing decade of the twentieth century and the opening decade of the twenty first century, as no national economy can operate independent of the global economy. From all indications this trend towards economic inter-dependence and integration is set to continue with leaps and bounds as twenty first century unfolds.[31] Indeed there is no better illustration of the interdependence between the various national economies than the 2008 financial meltdown which sent shock waves across the globe. Virtually no economy was unaffected as the global financial crisis made clear once and for all that the global economy could not be fixed without the active involvement and co-operation of all the stakeholders across the globe. What is clear, therefore, is that the global economy, as currently constituted, has huge impact on various aspects of the international system such that no country can operate outside of the global economy without serious repercussions as all economies are so tied to the world economy, that their fortune or misfortune depends considerably on the health of the global economy[32].

\subsubsection{Political Dimension of Globalization and the Question of Its Claim}

The second dimension of globalization we must now consider is political globalization. Commentators point out the strong link between economic globalization and political globalization.[33] Like economic globalization political globalization involves "intensification of interaction across national borders" especially in the area of governance and management of international affairs. Politics is about power and interest and negotiation to secure political control.[34] According to the Westphalia Treaty on which the current international system is built, nation-states are the sole actors in International affairs as each nation state is inherently defined by its sovereignty and territoriality, the fact that it recognizes no other political authority beyond itself and the fact that it has a well-defined boundary that physically sets it apart from other nation-states.[35]

The implication, therefore, is that international politics is nothing more than interaction between sovereign nation-states in which each one is motivated by self-interest, given the anarchic nature of the international system. [36] In such anarchic situation nation-states are sole actors in the sense that there is no supra-national authority to moderate the relationship among nation states, meaning there is high potential of conflict unless there is balance of power by way of harmonization of all the interests at play.[37] Here relations among states are often driven by competition rather than co-operation and even when they apparently co-operate it is still mutual self-interest that govern the relationship.[38]

Nonetheless one of the recent developments in international politics is the emergence of non-state actors as crucial voices in International politics.[39] Indeed, since the end of the First World War, there has been a steady rise in the number of International organizations involved in international affairs. The assumption behind their emergence is that international politics cannot be left to states alone but that non-state actors can play a significant role in limiting state actors, so that with their involvement there is greater likelihood of securing and maintaining peace among nation- states given that each state is driven by its national interest.[40] The implication, therefore, is that non-state actors such as International Organizations offer a stable and reliable framework for the promotion of co-operation among nation states.

This indeed is the philosophy behind the creation of the League of Nations by European Powers, following the end of the First World War. As the first of such International Organizations to become actively involved in the management of International affairs the mandate of the League of Nations was to work for peace in Europe and forestall the event of another war.[41] But we know, of course, that it did not fulfill that mandate as there was another war among European Powers, the Second World War which ended in 1945 with the United States emerging as the Superpower.

In the aftermath of the war, efforts to promote peace among nations continued with the founding of the United Nations which took over most of the functions and structures of the League of Nations but with an elaborate rethinking of its philosophy and mandate such as to make it more resourceful in mediating and maintaining peace among Nations.[42] Since the founding of the United Nations in 1945, not only has several other International Organizations emerged such as European Union, African Union, IMF, World Bank, but these organization have also become politically influential as far as the management of international affairs is concerned.[43]

Because they sometimes tend to undermine the sovereignty of nation-states in view of their transnational characters, some commentators are led to question the future of the nation-state, suggesting, as it were, that the current structure of the international system which is predicated on the Westphalia model may give way some day to a sort of supranational framework in which the relation between sovereign states is managed by a global authority, thus putting an end to the anarchic nature of the international system that has subsisted until now.[44] If and when that happens what we have is a cosmopolitan authority to which all nation-states comprising the international system will be answerable with regard to their operations. Some already see the European Union as a model of such future global government especially with the sort of economic and political integration it has 
accomplished in Europe.[45]

What is clear, therefore, is that with the emergence of non-state actors in international affairs, the business of managing the affairs of the international system is no longer merely a matter in the hands of nation states, as non-state actors are now significant stakeholders that limit the sovereignty of the nation state. This intensification and expansion of political interaction across the globe, with the effect of limiting the sovereignty of nation states is what is called political globalization.[46]

\subsubsection{The Cultural Dimension of Globalization and the Question of Its Claim}

Beyond economic globalization and political globalization, there is also a cultural dimension to globalization. Let us briefly consider what is involved in cultural globalization. As is well known culture refers to the totality of a peoples' way of life. It has several ramifications which include language, music, art, world views, food and the entire gamut of symbolic system of meaning.[47] Indeed, if there is anything evident about human nature it is the fact of culture. People are not the same in the sense that they have different cultures, depending on where they come from. The culture of Europeans is different from that of Africans just as the culture of Indians is different from the culture of Latin Americans. There is diversity in way of life and usually diversity is viewed as an element that enriches the human family generally as it means there is no single way of doing things, so that one way complements the other. Little wonder it is said that "variety is the spice of life".

There is nowhere this lesson is eloquently illustrated than in the area of culture. Diversity of culture may come with the challenge of tolerance and integration but once it is understood that diversity enriches, the assets of diversity far outweigh the liabilities. Like one's skin, culture is inseparable from the human constitution, so that wherever you find people you are such to find them with their cultures also; indeed, if we find different people we also discover that we have a diversity of cultures. Unlike economic and political globalization what are exchanged across borders in cultural globalization are cultural values, that is, people's symbolic system of meaning; hence cultural globalization refers "to the transmission of ideas, meaning and values around the world in such a way as to extend and intensify social relations."[48]

Such cultural exchange across the globe has always been the hallmark of human civilization, as people from various backgrounds interact through trade and commerce. In contemporary times, however, this cross border transmission of cultural values has been aided by the revolution in transport, as people take their culture wherever they go. Pertinent in this context is the phenomenon of migration. In the last couple of decades there has been mass movement of people across borders and as they move they carry along with them their culture as they transmit their culture to their host country.[49]

Little wonder, therefore, that these days we have all kinds of ethnic minorities within nation-states, thus making the configuration of the state more and more multicultural, as one culture asserts its claim within the political whole and resists reduction to another. Consequently, migration is arguably one of the key agencies of cultural globalization as far as contemporary globalization is concerned. We can also mention the media as another powerful agent of cultural globalization. Here, unlike the case of migration, the virtual ubiquity of the media ensures that without trans-verse of physical space cultural ideas are transmitted across the globe.[50]

We can think of the power of the mass media such as television, internet and all sorts of social media that define the contemporary landscape. Contemporary life will not be what it is without the influence of the media. One may not be wrong to suggest that contemporary life itself is paradoxically is a creation of the mass media; for, the media has exerted unprecedented influence in shaping people's understanding of life in the last fifty years. In fact some argue that the media is the most powerful teacher and in many cases it wields more influence than the parents at home or the teachers in the formal school.

You can imagine what contemporary life would be like without Hollywood or Bollywood, or again, without Nollywood. Without having to travel to America or live in America many people across the globe can identify with American life and culture through the mediation of American films that have acquired a global brand and provide an alternative to the local movies and films. Such identification, of course, does not come without being influenced and that has always been the case with the phenomenon of culture. What is true of American films and movies is also true of Nigerian films and movies transmitted across the globe by Nollywood. These give people who have never been to Nigeria or will never travel to Nigeria the opportunity to have a taste of Nigerian life and culture from their base and compare it to the local life and culture. Such is the power of the media and that is why it is, perhaps, the most powerful agent of cultural globalization.

\subsubsection{The Ecological Dimension of Globalization and the Question of Its Claims}

The fourth and final dimension of globalization we want to consider is the ecological dimension of globalization also known as environmental globalization. As the name suggests it has to do with issues associated with the environment and the management of the eco-system. More and more, people across the globe are coming to terms with the fact that the world belongs to everyone and if it must be preserved, everyone must play its role in ensuring that the environment is taken care of. Part of the challenges that have arisen in the contemporary context, therefore, has to do with matters relating to the degradation of the 
environment. In many cases this degradation is a knock-on effect of industrialization and technology; for, as oil companies drill the environment for gas and oil they cause damage to the environment. It is either oil is spilled into the ocean, so that marine life becomes endangered or the emission of green gas lead to global warming which in the end effects changes in the climate.[51]

Awareness is growing more and more that this cannot continue without check, if the environment is to be preserved. Environmental globalization has to do with the globalization of concern to save the environment. Both governments and non-governmental organizations under the leadership of United Nations are involved in this drive.[52] Efforts to save the environment usually assume the form of Treaties which governments across the globe are asked to sign up to, as part of their commitment to preserve the environment, bearing in mind that environmental degradation usually stems from man's economic and technological activities.[53]

Take the case of global warming and climate change which has been directly linked to greenhouse effect. Realizing the implication of this for the health of the environment and humanity, scientists backed up by non-governmental organizations call for immediate action by governments to curb green-house emission. [54] This was a key focus of the Kyotto protocol set up by the United Nations, following the Conference on Environment and Sustainable Development that took place in Japan in 1997. Other International Treaties which express global concern to save the environment include the Johannesburg World Summit in 2002 on Ecological Sustainability, pollution; Rotterdam Convention of 1998 on Industrial pollution and Vienna Protocol of 1985 on Ozone layers. All of these Treaties and several others are at the service of mobilizing global co-operation on the matter of environment and to this extent express the environmental dimension of globalization.

\subsubsection{Globalization and the Dialectic of Identity and Difference: Some Critical Issues}

Having examined the various dimensions of the phenomenon of globalization we have seen how each of the dimensions illustrate our understanding of globalization as the intensification of the process of interaction between peoples and nations across the globe, with a view to achieving integration at various levels: economic, political, cultural and environmental. At this juncture a number of critical issues arise. First how are we to understand the interrelation between the various dimensions of globalization? Can we identify globalization exclusively in terms of any of them? In other words: is any of the dimensions supreme with respect to its claim as far as expressing the logic of globalization is concerned?

Sometimes the tendency in some studies is to identify globalization with economic, political or cultural globalization. But, as Steger correctly notes, this is a questionable approach; for, each of the dimensions is important and unique in what it contributes to our understanding of globalization, so that we simply mutilate the concept, if we explain it away exclusively in terms of one of its dimensions. [55] What is clear, therefore, is that all the dimensions must be taken into account. Yes each dimension expresses the reality of globalization; yet none of them exhaustively expresses the full reality of globalization.[56]

Indeed, it is like the proverbial elephant with many ramifications, so that different persons see it from its different aspects. But unless they understand that we are dealing with the same elephant the temptation is to think they are talking about different subjects. To do justice to the reality of the phenomenon of globalization, therefore, requires that its complexity be taken account, as it emerges that each of the dimensions is irreducible in its claim relative to the meaning of globalization.[57]

The second issue we must raise concerns the question of the dialectic of identity and difference, as it pertains to the dynamics of globalization. Arguably this is an issue that will arise in respect of any form of social interaction. In the specific context of globalization, the question we must ask is whether it is a good thing or a bad thing in the final analysis, given that the process of promoting global interaction and integration can easily sacrifice identity at the altar of sameness, since the concern is not with the particular in its particularity, but the particular from the standpoint of how it sub-serves the whole and what it contributes to the integrity of the system [58].

The situation of nation states vis-à-vis contemporary globalization eloquently illustrates this point. This is true in respect of political globalization or economic globalization or indeed in respect of any of its dimensions, so far as globalization seemingly threatens the autonomy of nation-states to act in their own best interest, if, for, instance, the local economy has to be tied to the global economy and the nation state has no control over the workings of the global economy; or, again, if the nation-states have to be constrained in the exercise of their sovereignty by forces of political globalization they apparently have no control over.[59] The same issue is evident in the context of cultural globalization; for, given that globalization tends to promote popular culture, the cherished values of different people may be negatively challenged or undermined by the forces of cultural globalization, as some critics have noted concerning the propagation of American values through the means of the global television network.[60]

In view of these limitations, it is not surprising that some commentators affirm that globalization is a bad thing and therefore should be discouraged.[61] Nonetheless what is evident is that, like most things, globalization has its own benefits without prejudice, of course, to its limitations, so that, in the final analysis, the issue is always a question of how one relates with globalization and one's overall 
motivation and perception.[62] In other words, depending on how weak or strong a participant one is, in the global affair, one would tend to have different views about the possibilities and limitations of globalization. There is no doubt that the dominant powers will tend to favor globalization, since overall they stand to benefit maximally from it, whereas, on the other hand, weak parties will tend to condemn globalization, since, for the most, they are seemingly helpless in the final analysis and must depend on a global system they have no control over.[63]

What is clear is that this scenario is inevitable, given the anarchical nature of the international system and given the further fact that participants in the global affair are driven by sheer self-interest even when they apparently seek to co-operate with other participants. Thus unless one advances one's interests, the risk always is that one would be at the mercy of the global system, so that one is unable to maximize the opportunities inherent in globalization.[64] The basic truth here is that, like in all social interactions, the opportunities for growth and self-development are always immense but what one makes of them all depends on one's ability to operate in terms of one's priorities and interests, so that at each point of the encounter one is always in control of one's destiny. That is the only way to guarantee that one would make the best of the opportunities inherent in such encounters.[65]

\section{The Question of Impact of Globalization on Africa: Crisis of Confusion and Identity}

In interrogating the impact of globalization on Africa in what follows, it will emerge that the foregoing considerations are of crucial importance in assessing whether or not Africa has made or is making the best of the opportunities inherent in globalization or, again, whether in the end globalization is a good or bad thing for Africa. There is no gainsaying that, like in other continents where the impact of globalization has been concretely felt the impact of globalization on Africa has been phenomenal. Not only has it brought innumerable benefits to Africa, but more importantly there is no aspect of social and national life that has not been concretely affected by globalization. Perhaps the most obvious area where its impact has been concretely felt is the area of information technology and communication.[66]

\subsection{Mobile Telephone and the Question of Impact of Globalization on Africa}

To start with, let us take the case of mobile telephone. Up until recently, majority of Africans did not have access to telephone, as it was a luxury which only the rich, government and private institutions could afford and, for the most part, when the services were available, it was always difficult to secure a telephone line. In some cases there could be a waiting period of almost a year or more; and moreover one could not guarantee the quality of the services once the line was installed because most of the national telecommunication outfits were either poorly funded by government or they were ridden with corruption and mismanagement, so that the facilities were hardly well maintained, thus resulting in inefficient productivity.

The advent of mobile telephone less than twenty years ago, and the liberalization of access to telephone that came with it, has drastically altered the situation. For, more and more people now irrespective of their socio-economic status possess mobile telephone and do not need to go through any bureaucratic process to obtain a telephone line as was the case hitherto. Compared to what obtained hitherto this is simply a telecommunication miracle made possible by globalization. In fact in the last few years the cost of owning a mobile phone has come down considerably as well as the cost of making calls, so that more and more people are able to afford it, even in the remote hinterland and villages. Indeed it is so common now that it looks odd for one not to have one now. Yet less than twenty years ago no one could imagine that the situation could be what it is today. In fact, it is estimated that the fastest growing industry in Africa today is the telecommunication industry.

The result of this revolution in telecommunication is evident in every aspect of social and national life throughout the African continent.[67] Because of mobile telephone there is improved inter-personal communication as people can communicate with friends and family with ease, without having to travel long distance to see them. Similarly they can connect with friends and families abroad simply by calling from their room or wherever they are, just as mobile telephone is also helping to bridge the vexed divide between rural life and urban life since one does not have to travel to the village or town in order to keep in touch but could keep in touch Twenty four-seven in real time and monitor the situation of things by simply telephoning.

The advent of mobile telephone is also transforming the way business is done in Africa as many transactions can be initiated, processed and consummated on the telephone before one even gets to the office. Similarly appointments can easily be fixed, reviewed, cancelled or rescheduled without having to see the person physically in order to do so. What this means is the possibility for better planning and time management which in turn affects efficiency and productivity positively. Without doubt this is a significant improvement upon what obtained hitherto. The advent of mobile telephone simply means that business can be conducted more effectively and efficiently with minimum of cost and hassles in real time.

\subsection{Internet and the Question of the Impact of Globalization on Africa}

What is true of mobile telephone is true even more of the 
internet as the internet offers more possibilities for social interaction. In the early days of the internet in Africa, internet services were provided generally by cybercafé and it remains so to a large extent today. But with the advent of broad band and the integration of mobile phone and internet in one device, such that one could surf the net on one's telephone as well as send or receive e-mail simultaneously, there has been a certain liberalization in internet services as one could access the web anywhere or at any time, meaning that the possibility of staying connected all through the day via the internet is widely improved.

Little wonder that with the liberalization of the internet there has been a significant rise in the number of social media that have come up such as Linkdel, Whatsapp, Facebook, Badoo and Instagram. All these modes of interaction beyond national boundaries have had unbelievable impact on social life in Africa; for, as never before people can connect and even exchange materials online in real time. In many places in Africa, even before an event or ceremony is over pictures of the occasion are already awash in the internet and the social media. Not only is it the case that people access these materials but interestingly some virtual communities emerge where people converse on these materials in real time.

But aside from the impact that mobile telephone has had or is having on social life, there is also the case of research and how it is being affected by the internet. Here the basic truth is that the advent of the internet has made research easier in Africa. Part of the bane of the academia in the past and still now is the dearth of literature. Many libraries in Africa are under-funded, so that recent stocks in various fields of learning are hardly available. In this sort of deprived situation engaging in academic research can be extremely difficult; for, without literature research can hardly be done nor can we guarantee the quality of the research without sufficient literature.

Yet the truth is that many libraries in Africa are under-funded and so are not well stocked with relevant literature in various fields of learning. One can hardly find recent journals in many universities due to the high cost of journals and paucity of foreign exchange, these institutions hardly subscribe to international journals. In some cases when funds are voted for this purpose, the funds are never used for the purpose but end up in private pockets.

With the advent of the internet however, students across the African continent are able circumvent this unbelievable obstacle to academic research by simply googling up the topic. The immense influence of such facilities as Wikipedia, the free encyclopedia, Stanford Encyclopedia of philosophy, Internet Encyclopedia of Philosophy, and other innumerable electronic journals and facilities for online research cannot be over-estimated. There is virtually no topic one googles up that will not yield a vast amount of resources for research. This means invariably that even amidst the dearth of relevant literature in the physical library the African student can still manage to conduct quality research even in the remote hinterlands, provided he can connect to the worldwide web. This is all due to the impact of globalization. Thanks to globalization vast amounts of materials can be accessed and exchanged on the internet.

Indeed, just as the mobile telephone has liberalized telecommunication, the internet has also liberalized research such that it is now possible for the student in real time to have more materials than his teacher in class if he is connected to the internet as the lecture is going on. In fact, in many cases as the teacher lectures in class the student is able check the topic under discussion by going online and searching for additional materials on the internet. It is difficult to over-estimate the impact of this revolution on academic research in Africa and the basic truth is that the student is better for it. With the sort of corruption and inefficiency that bedevils the management of education in many parts of Africa today one imagines what will be the situation of education and research without the internet.

\subsection{Banking Industry and the Question of the Impact of Globalization on Africa}

When we turn to the banking industry the story is no different in respect of the impact of globalization on Africa. For, globalization has meant a new lease of life for the banking industry in most parts of Africa. With the facilities provided by mobile telephone and internet and indeed the whole revolution in telecommunication the way the banking industry is operated is changing rapidly. Sensitive data and information are processed are managed more efficiently with minimum of time. Because of these people spend less time in the bank just as banks are also able to attend to more customers and manage many more accounts.

This is a sharp contrast to what obtained hitherto when one could spend a whole day in the bank with nothing to show for it sometimes as the business cannot be consummated but must carried over to the next day. The days of banking with nightmare is almost over in many parts of Africa as the revolution in the telecommunication is making banking less stressful. Because of the computerization of data it is possible now in many banks across Africa to do online banking and to even withdraw money from ATM. This was simply unimaginable a couple of years ago. The transformation that is sweeping through the banking industry is simply unbelievable as it is re-positioning African banks to compete with their counterparts in the global market.

It is not only in the area of customer service that globalization has impacted positively on the banking industry in Africa, the impact can also be seen in the manner in which the banks have opened up to the global market and in many cases they enter into partnership with foreign banks, meaning that they have real time access to 
the global market. Because of the connectivity to the global market it is possible now for money transfers to be done through the banks almost in a minute or so. Not surprisingly many money transfer agencies are operative in the banking industry across the African continent.

We can think of such outfits as Western Union Money Transfer or Moneygram, or Ria and several others. That money can be transferred through the banks and received almost instantaneously by the customer at the other end has impacted tremendously on the operation of the banks as well as business and economy in general. For the fact that money can flow easily and with minimum of time means that business can proceed efficiently not only within the countries but across national borders. It is estimated that money remitted by Africans in diaspora constitutes a large amount foreign exchange earnings for many African continent. There is no doubt that without the benefits of globalization such transfers could not be done.

\subsection{Greater Openness to the Global World and the Question of Impact Globalization on Africa}

What is true of the banking industry and education and telecommunication could easily be shown to be the case in respect of other areas of social and national life in many African countries such as transportation, health, sports, entertainment industry and several others. The impact of globalization here has been no less significant and what we see all the time is that as a result of globalization, Africa is opened up and connected to the larger world. This trend of opening up and connecting to the global world is sure to continue for a long time to come especially with the popularity of the cable network television which can be found in every nook and corner of African towns and villages. This connectivity to the global world means that things happening in other parts of the world can be viewed in real time, with the result that the African situations can be compared to the situation of things in other parts of the world.

This access to real time happenings in other parts of the world through the global network television and internet has impacted tremendously on Africa's self-understanding of itself and in many part of Africa this awareness is spurring Africans not only to raise critical questions about the general situation of Africa and its predicament vis-à-vis other continents, but it is also making Africans to demand transparency, accountability and good governance from their government as it becomes evident that Africa is backward compared to other parts of the world.[68] This collective awareness of backwardness of Africa on the part of its people and the demand for good governance arguably is part and parcel of the impact of globalization on Africa, if we consider that it is this opening up to the global world that is behind this self-interrogation and demand for accountability.[69] Consequently it means that from whatever angle we view the matter the impact of globalization on Africa is seemingly immeasurable.

\section{The Impact of Globalization on Africa and the Question of Crisis of Confusion and Identity}

Yet while the impact of globalization on Africa is undeniable as evidenced by the concrete cases we have examined above, the question is: what has Africa been able to make of her openness to the global world, especially in view of her growth and development? Is Africa really making the best of the situation?

Has she been able to turn the opportunities inherent in globalization to her own advantage? Ceteris paribus, every social interaction that is healthy should serve to enrich the participants, if approached with the right attitude and disposition, as it comes with immense opportunities for growth and self-development. Unfortunately, the story of Africa is quite the contrary, for her encounter with globalization apparently has not helped to pull her out of poverty.[70] Instead the incidence of poverty seems to have increased with leaps and bounds across post-colonial Africa, so that paradoxically she has been unable to fulfill the great promise that greeted the dawn of independence from colonial rule.[71]

One major factor that explains her failure to turn the immense opportunities inherent in her opening up to the global world to her advantage concerns her mode of engagement with globalization. What is evident is that the relationship is unbalanced and it could not be otherwise, if Africa is not engaging the global world in terms of her interests and priorities.[72] The basic truth is that one's identity is a function of one's interests and priorities, so that not to be clear about one's interests and priorities, or again, not to relate with others in terms of one's interests and priorities is always bound to have an adverse effect on one's understanding of his identity. Thus in the event of any encounter with the other, one's power of negotiation is considerably weak.[73]

Indeed this point aptly captures the situation of Africa in the face of her predicament; for, given that she relates with the global world in terms of considerations marginal to her priorities and interests, her ability to compete with other participants in the global world on equal terms is grossly undermined, meaning that she is unable to turn the opportunities inherent in globalization to her own advantage. The result of this is that her encounter with globalization provokes a crisis of confusion and identity for her, as she is apparently at the mercy of the forces of globalization and not in control of her destiny and to this extent Africa is unable to harness her resources in developing her potentials.[74]

Whether in interpersonal relations or international relations or any social relations for that matter, it is always a terrible thing not to engage the other in terms of one's 
interests and priorities; for one is not only left confused by such interactions, but one is also unable to assert oneself, so that in the face of inability to assume personal responsibility for oneself one also runs the risk of being preyed upon and abused by the other. The end result of such mode of engaging the other is the loss of self confidence in one's ability to take control of one's destiny, so that one begins to look unto others to do for one what ordinarily one should do for oneself.[75]

What is more: the loss of self-confidence that arises from such unhealthy pattern of relationship also breeds inferiority complex that always makes one to consider the other better than oneself without really caring to do justice to one's inherent abilities. So it is clear, therefore, that we are dealing not just with a crisis of confusion and identity, but more importantly we are dealing also with a crisis of confidence and dependency.[76] With loss of self-confidence one comes to depend more and more on the other and it remains to be seen whether when the chips are down, the other can adequately cater for one's interest as one would cater for them oneself, especially when the environment of engagement is one of unbridled self-assertion and stiff competition.[77]

No doubt this analysis enables us to understand why Africa has not been able to turn the resources of globalization to her advantage; for, if, in truth, she does not engage other participants in the global world in terms of her priorities and interests, her opening up to the global world can hardly advance her interests but will only serve as avenue for others to take advantage of her, so that she ends up becoming a dumping ground for others while her real needs are not met. In other words she ends up contributing to the development of the other while she herself remains underdeveloped.[78]

In this sense Africa not only becomes a consuming economy that serves to service the global economy, but in the process she seemingly loses the ability to fend for herself, so that she finds herself enmeshed in a circle of dependency that is dialectically sustained by her crisis of confusion and identity.[79] Unclear about her priorities and interests or rather, unable to assert her priorities and interests in her engagement with the other, she is easily lost in the sea of global competition while unrealistically waiting for assistance from other competitors in the global affairs who, as a matter of survival, must also struggle to assert and secure their own interests.[80] In an anarchic world of international affairs driven by self-interest more than altruism one can expect nothing less, so that one must blame oneself, if one fails to rise up to the challenge of fending for oneself.[81] Paradoxically that is the sort of crisis of dependency that Africa is caught up in, so that, it is not surprising if she has failed to turn the immense benefits inherent in globalization to her advantage.

It is important to stress the point of the correlation between the law of interest and priorities on the one hand and the law of development on the other hand, as far as the whole question of turning the benefits of globalization to the overall purpose of one's development is concerned. Without securing one's interests and priorities there can be no growth and development. As it were each one must live his life and die his own death, as he must also fight his own battles. One can never abdicate personal responsibility for this and leave it others otherwise there is no show.

Our contention is that Africa has not being able to fulfill the demands of this correlation of interests, priorities and development, hence her opening up to the global world has not been able to pull her out poverty. What Africa's case painfully demonstrates is that one could easily enjoy the benefits or "goodies" of globalization without necessarily being aided by these to climb up the ladder of development so far as one's real needs are not addressed. In such event while one enjoys the goodies it barely scratches the surface, so that fundamentally the situation remains unchanged as one remains stuck in poverty as in the case of Africa.[82]

We can illustrate this point by returning to the concrete cases we cited as evidence of the impact of globalization in Africa. Without taking back the point we made in praise of globalization, the crucial point is that in each of the cases we examined something fundamental about the nature of African predicament remains unaddressed even amidst the celebration of the goodies of globalization under the guise of mobile telephone and improved communication it brings about, or again under the guise of internet and improved social interaction in real time it brings about, or again, under the guise of the succor it brings to African students in terms of academic research in an environment bereft of well funded and well stocked physical libraries. The same must be said of the goodies of globalization under the guise of improved banking services and the opportunity to receive remittance from loved ones abroad within a matter of minutes, or again in respect of the goodies of globalization in the area of health and transport. No one in his right senses will fail to credit globalization for making things easy where in fact the conditions are unbelievably deprived.

Yet without prejudice to all these accolades of globalization, the point is that in each case there are fundamental needs that require to be addressed in the absence of which it almost amount to placing the cart before the horse.[83] An African artiste once posed this challenge. Suppose you were faced with the option of choosing between money, child or peace, which one would you settle for? Peace, of course, one would answer if one was not to choose only one. But if one were allowed to choose more than one, there is nothing wrong in having all of them provided the order of priority is respected, namely, peace, child and money. If one were to choose only one it would certainly be foolish to prefer either money to peace or to child.

The point here is not just that there are priorities but more importantly there is hierarchy of priorities so that if one's priorities are properly ordered one should begin with 
higher values before settling for lower values. This point is germane in the present context of assessment of the goodies of globalization and the real interests and priorities of Africa. No one would deny the pertinence of mobile telephone or internet. Yet one would question one's sense of priority where mobile telephone or internet service is prioritized over and above constant electricity power supply or good roads and other infrastructures or their maintenance. The two services definitely should not be set in dualistic opposition as they are not exclusive opposites, yet the point is that where priorities are well ordered one must come before the other, so that if there is no constant power supply one would wonder why mobile telephone and internet service should be prioritized when in actual fact power supply appear to be more fundamental in terms of how it affects people's life and the entire economy. Or, again, one must wonder why mobile telephone must be prioritized, if there are no good roads or if they are not maintained thus compelling people to get involved in a rat race to own a jeep in order to cushion the effects of bad roads. If we must have mobile telephone and internet then we must also have constant power supply and good roads otherwise something is wrong with our sense of priority.

Indeed the need for power supply is so urgent that it requires first attention; for, in truth it is first in the order of priority no matter how we value things. The same argument must be effective in respect of the other goodies of globalization as far as the African situation is concerned. I mean the correlation between internet and academic research or again the correlation between internet and banking service. In all these cases, the law of priority requires that we cannot run after other values if a higher value is begging to be secured. How can we say, for instance, that we can do without the physical libraries? How can we say we can do without physical classification of documents? How can we say we can do without the landline telephone and all the facilities that come with it in respect of fax and so on?

The situation is somewhat inexplicable but when properly interrogated it emerges that in cases where priorities are misplaced and interests marginal to the overall welfare of people are promoted, we are really dealing with a situation of corruption. For, the basic truth is that corrupt politicians and local merchants collude with foreign investors to ensure that policies that conduce to their interests rather than the national interest are what prevail in the end. While one cannot blame globalization for this, for the reason that each participant in the global affair must fend for itself, it is evident that so long as this continues the circle of dependency cannot be arrested and it means that Africa will continue to fail to seize the opportunity of globalization to climb out of poverty.[84] If Africa is not projecting its interests in engaging with the global world and as a result is not maximizing the opportunities inherent in globalization, the question is what must be done to reverse the situation of dependency and the under-development it occasions?

\section{Globalization, the Question of Locus of Control and the Imperative of Internal Democracy}

Walter Rodney wrote a book in which his main concern, as the title of the book suggests, is to account for how Europe under-developed Africa.[85] Rodney's book has been highly popular in postcolonial theorization of African predicament. While the point of Rodney's thesis is incontrovertible, considering the several centuries Africa was under the yoke of foreign domination, first through the Trans-Atlantic Slave Trade and subsequently through Colonialism, it is arguable that Africans played a great role in the underdevelopment of Africa, so that Rodney's thesis could be turned round, to the effect that we begin to interrogate how Africans underdeveloped Africa. For, the basic truth is that in any form of social interaction it always takes two to tango and when something goes wrong in the relationship, it is important to approach the matter from the standpoint of the two polarities of the self and the other. [86]

Unfortunately, more often than not attention has always been focused on the polarity of the other in attempt to theorize the cause of the African predicament, while paying little or no attention to the polarity of the self. Indeed, as the matter stands currently, whether in respect of Africa's encounter with slave trade or her encounter with colonialism or again her encounter with globalization we cannot understand the inner dynamics of Africa's underdevelopment unless the inter-play between the self and the other is taken into account, without necessarily setting one in dualistic opposition to the other for in truth the self and the other are not exclusive opposites but complimentary pairs that mutually determine the destiny of each other.

Indeed in advancing his thesis Rodney has definitely done Africa a lot of service. Yet it is important to recognize that it is no less a significant service, if we focus on the role of Africans in making it difficult for Africa to climb out of the cycle of dependency and poverty she is caught up in. As noted the Achilles heel of Africa is lack of clear focus in respect of her priorities and interests as well as failure to allow her interests to drive her engagement with other participants in the global system.

\subsection{The Question of Locus of Control}

The basic truth is that very often the burglar hardly operates alone but breaks in with the active assistance of an insider who knows the terrain very well. Sadly enough, in the case of Africa, it is a well-known fact that Africans have often played a key role in colluding with foreigners to sabotage the interest and priorities of Africa at the altar of 
personal gain, so that, in the end, Africa finds herself at the mercy of forces beyond her control. The incidence of slave trade and colonialism cannot be fully understood without reference to this consideration. Paradoxically, it is as if history repeats itself, and Africa seemingly fails to learn the lesson of history, the incidence of the failure of Africa to take advantage of the opportunities inherent in globalization cannot be understood without reference to this consideration as well.

The point is that, if Africans will sell themselves out in this way and fail to protect their own interest, the center can hardly hold. Things are bound to fall apart. It is a scenario that repeats itself again and again, as if to say there is failure to understand that group interest supersedes personal interest, so that on no account should one ever collude with outsiders or even insiders in sacrificing the group's interest at the altar of personal convenience otherwise one mortgages the future of posterity for a pot of porridge in the short term.[87]

I think this is the dark side of Africa's role in her underdevelopment that is often glossed over at the expense of interrogating the role of the other in causing Africa's predicament. To focus on the other while glossing over the role of the self is certainly convenient and perhaps is symptomatic of certain will to power. But it can hardly yield any lasting panacea. The path of self-interrogation is painful. Yet it is a painful moment of truth that must be allowed to prevail if there is hope of return of sanity.

In view of this consideration a moment of self-interrogation is a sine qua non in dealing with Africa's predicament.[88]Indeed to reverse the situation of dependency which basically stems from Africa's current mode of engaging with the global world in terms of considerations alien to her fundamental interests and priorities, there is urgent need for Africa to relocate her locus of control internally by turning the search light on herself and her operations. In other words Africa needs to take a step back from her situation in a moment of self-confrontation and take responsibility for her situation rather than merely locating her locus of control externally. She needs to come to terms with the reality of her situation by looking inward rather than merely outward in attempt to understand and sort out her situation of crisis.[89]

While the other may have played a role in causing the situation of dependency and perhaps still plays a role in sustaining the situation, to come to grips with the inner dynamics of what enables the situation to arise and remain from the standpoint of the self, is without doubt a sort of self-empowerment to begin to re-assume personal responsibility in respect of understanding the crisis situation and how best to sort it out. The truth is that it is not likely that an outside will bring the needed solution especially given the anarchic nature of the international system as we have noted. The help must come from inside and when it comes from inside there is a guarantee that it is not only well anchored, but more importantly there is a guarantee that it will be durable in its ability to match up to the challenge on the ground.[90]

Like in all crisis situations strategic thinking is required in order to get out of the woods and we do not think strategically when we pass the bulk and locate our locus of control merely externally instead of also internally. Instructively in respect of African predicament the strategic thinking required to escape from the woods has to be done by Africans themselves without prejudice to the help that might come from outside. Indeed whatever helps might come from outside still require to be internally appropriated if one is to be in the saddle of navigating one's predicament.

It cannot be over-emphasized that crisis is always a blessing in disguise if its hidden treasures are properly understood and well utilized. If Africa would locate her locus of control internally and allow her priorities to legislate her action and operations in the global world, her crisis of confusion and identity in the face of globalization will become an occasion for self-rediscovery and renewal of commitment to the pursuit of excellence internally and externally.

One hears again and again in discussions concerning African predicament that Africa is a continent rich in natural resources but paradoxically Africa has not been able to translate her potential greatness into actual greatness owing largely to corruption and mismanagement of her resources, albeit she has also suffered centuries of exploitation and abuses and perhaps continues to do so even now. Yet the moment Africa is able to relocate her locus of control internally and assume responsibility for her destiny, as suggested, it will dawn on her that the solution to her predicament lay in her hands.[91]

\subsection{The Imperative of Internal Democracy}

But the question is where does she start from in sorting out her mess? There can be no other starting point than to put in place a strong tradition of internal democracy, for her failure to breakthrough stems from lack of organization and not necessarily from lack of resources, human and natural. With a strong tradition of internal democracy she will begin to re-organize herself and ensure that her resources are harnessed towards meeting her real needs. When Clinton visited Nigeria he noted that the problem of Nigeria is not that she lacked intelligent people but rather that there is lack of organization.

Clinton is right and perhaps what is true of the Nigerian situation is true of Africa as a whole. In virtually all fields of human endeavor there are Nigerians and indeed Africans who have proven that they can compete with the best in the world and excel. Indeed in many cases when they find themselves outside Nigeria they spring surprises with their performance as they demonstrate the stuff of which they are made of. In an environment that is enabling, an average African with minimum of effort will perform wonders.[92] 
But the problem is that back in Africa the entire environment is not enabling. If one were thrust into a system that is dysfunctional even if one had potentials one would probably fail to realize one's promise. This is the story of many Africans but as soon as they leave the shores of Africa the situation changes dramatically as they discover that they can do great things. If this is the case, it means that Africa must begin to take a hard look at how things are done within it. There is need to interrogate the system and make adjustment where there is need for adjustment.

First and foremost the adjustment that needs to be made pertains largely to attitude. There must be a basic return to the principle of honesty is the best policy, especially as it pertains to how resources are expended. This is one hallmark of democracy that Africa must insist upon. Because of many years of military rule, very often due process is not followed in the way things are done. And so long as things are not done properly the system runs the risk of being dysfunctional. The truth is that if the resources of Africa will be used judiciously for Africans there is no African that will be poor. The resources will be enough to take care of everyone. But where corruption is rampant and a few people seat on what belongs to all, the cycle of poverty and dependence is sure to continue.

When Obama visited Ghana a couple of years ago he told his audience that Africa does not need strong individuals but strong institutions. Obama is correct. The hallmark of democracy is the rule of law. And where rule of law is the modus operandi everyone is equal before the law. No one is above the law and what is good for the goose is good for the gander. With a situation where everyone is equal before the law and is held accountable for his actions, it will be much easier to tackle the problem of corruption which indeed is the major source of destabilization of the African society. Africa must really begin to insist that no one be treated as if he is above the law. The interest of the system must supersede the interest of any individual and this can be done only by ensuring that there is balance between private and public interest.

The current situation where excessive attention is paid to private goods by Africans must give way to a new regime that prioritizes public good over private good; for, if the sanity of the public realm is guaranteed there is likelihood that everyone will be taken care of as much as possible. No system can work if the public realm is neglected. This is why it is important to entrench rule of law as the basis principle of operation in every ramification of national life.

Of course this will take a great deal of discipline but it is worthwhile investment for if things begin to be done properly gradually the mess will be cleared up. A system that works is in the interest of everyone and everyone should really work to make the system to work, for it the system works the security of everyone is guaranteed. On the contrary if the system is dysfunctional then people are forced to resort to short cuts and this can only make the situation to be worse as we are back to a state of nature.

I think this reflects the current situation in many African countries and that is why it is really a situation of mess. Just like independence, democracy can be an empty concept, so far as its spirit is not allowed to take hold in a system. One can profess to be independent only by mouth when in actual fact one is not truly independent if in fact one is not in control of one's destiny. The same anomaly can occur, if one claims to run a democratic system when in fact there are not strong institutions but strong individuals. We cannot really speak of true democracy if things are not done properly and this is where Africa has to begin to sort itself out. Once this happens the system naturally becomes transparent and accountable. In a system that is transparent and accountable the individuals that make it up have no choice than to be accountable otherwise they will face the wrath of the law. The law is there to regulate the system and when it is allowed to be so, the task of political engineering becomes much easy to undertake despite all the challenges it entails.[93]

There is a strong correlation between one's internal affairs and one's external affairs. If one's internal affairs are poorly managed it is bound have a negative conditioning on one's external affairs. The way to guarantee strong external relations is by ensuring that one's internal affairs are properly sorted out and if this happens it is indeed an investment for one's external relations, for it is nothing but image laundering of a sort. No one will take seriously anyone who is unable to manage his internal affairs.[94] Not only will he not command the respect of his peers but he will never be trusted such as to be entrusted with serious responsibility; for, if he cannot handle his own internal affairs there is likelihood he will not manage well his relations with others or matters that pertains wholly to others.

So it is evident that the state of one's internal affairs is crucial to the well-being of one's image and that is why in addressing her predicament a sure place to start is for Africa to sort out her internal affairs through the mechanism of a strong regime of internal democracy. If this happens African will break the cycle of dependency and re-earn the respect of the comity of nations. There is no doubt also that this development will improve Africa's negotiating power as far as her engagement with other participants in the global affair is concerned.

Respect is not something one demands but it is something one earns by showing that one is worthy of respect. There is no doubt that if Africa sorts out her internal affairs properly, she will recover her self-confidence to assert her rights and to operate in the international arena in terms of her interests and priorities. So it emerges therefore that nothing is as important as instituting a strong tradition of internal democracy as a first step to recovering the ground that she has lost. It will be a painful process but it is one that is worth it and the earlier it starts and is sustained the better; for, it means that in no 
distant time the situation can be turned around drastically, as Africa re-discovers the motivation to operate in terms of her interests and priorities. Indeed, if attention shifts from over-emphasis on strong individuals to a culture of vibrant internal democracy, Africa will re-assume control of her destiny and this is sure to enhance her capacity to participate effectively in the global scene and turn the opportunities inherent in globalization to her advantage.

\section{Globalization, Neocolonization and the Question of Sustainable Development}

While the foregoing is incontrovertible, there is no denying the fact that globalization has neo-colonialist trappings. This is especially evident with respect to economic globalization and political globalization. African countries are supposed to be sovereign nation states with control over their economic and political destiny. But in reality they often lack such control as they are still tied to the apron-string of their erstwhile colonial masters, so that key decisions that affect their economic and political destiny are really not in their hands but are remotely determined and controlled by Washington, London, Paris, Brussels and Berlin. Thus because of the neo-colonial structure of the international system and its inherent determinism as well as its lopsided power-relation in favor of erstwhile colonial masters who control the international system, the claimed independence of African countries really amount to mere paper independence without much cash value.[95]

Consequently, while they are condemned to operate within the international system, as no nation can operate in isolation, their voice count very little in constituting the norms that govern the international system, norms which often reflect and protect the interests of the rich nations of the global North to the detriment of the interests of the poor countries of the global South, especially African countries. That the international system is lopsided with regard to its power-relations not only compromises the destiny of poor countries of the global South, but it also leaves them vulnerable to exploitation by the rich nations of the global North, so that the inherent dynamics of the international system leaves the poor countries in a rather weak and helpless position. In other words, the neo-colonial and seemingly deterministic nature of the international system does not really give African countries much chance with regard to what they can really do to help their situation.[96]

What it means therefore is that even in spite of their best effort, if they could boast of such, the inherent dynamics of the international system precludes the possibility that these countries can ever climb out of poverty unless the norms of the international system are revised to allow for a balanced relation that reflects the mutual but competing interests of all stake-holders. Unless the structural injustice and inequality that bedevils the inner workings of the international system is redressed there is little hope for poor countries of Africa, as they are sure to get poorer amidst the global wealth generated by globalization within the international system.[97]

Obviously the situation leaves us with a scenario where some profit tremendously from globalization while others do not. The rich get richer while the poor get poorer with the net result that globalization widens the gap between the rich and the poor, with many descending further into poverty instead of climbing out of poverty all thanks to the inequality and injustice that characterize international system and indeed international relations. This whole development has led some commentators to ask whose interest globalization ultimately serves. Whose globalization? Whose International system? The answer is not really far fetch, if the norms that govern the international system do not equally provide for nor balance between the competing interests of all stakeholders, but privilege the interest of some over others.[98] Indeed, on account of this consideration some argue that globalization ultimately serves the interest of the rich and powerful, hence the correlation established between globalization and neo-imperialism or neo-colonialism as globalization is seen as a vehicle for the propagation of Western hegemony.

From the standpoint of the question of African identity, the foregoing point is significant for it offers us a further window for visualizing the nature of African predicament, so that beyond the imperative that African countries need to assume responsibility for defining their priorities and organizing their life in terms of these, there is the further question as to whether the neo-colonial and deterministic structure of the international system will allow her to do so. Let us take some examples to illustrate this point.

One obvious example is the case of international trade between African countries and developing countries of the global North in which the balance is clearly in favor of the erstwhile colonial masters. As part of hangover from the colonial past African countries specialize and have continued to specialize in servicing the economy of developing nations by producing raw materials for their industries. The developing countries in turn process the raw materials into finished products and sell them to African countries. They pay virtually 'peanuts' for the raw materials and sell the finished products at exorbitant price.

The trade relation between the two parties is clearly instrumental and exploitative in the sense that it is driven by the needs of the developed nations and hardly takes into account the interests of African countries beyond using them to service their economy, so that African economy becomes but a moment in the global capitalist economy that promotes the hegemony of the nations of the global North. The net effect is that the economy of African countries becomes 'consumer' economy as African countries are turned into dumping grounds for Western goods and services thus compelling African countries to 
depend wholly on external forces with respect to what they produce, what they import as well as what they export.[99] This procedure not only undermines genuine African initiatives motivated by African interest, but it also forecloses the possibility of African economy transforming from a rural agricultural economy to an industrialized economy. Yet so long as African economy remains a consumer economy such transformation is hardly feasible for the economy is ultimately at the service of the global capitalist system and not at the service of genuine African interest.[100]

In view of this consideration it is not surprising that African countries have been unable to achieve economic self-reliance despite several decades of post-colonial experience and the great expectation that independence from colonialism unleashed. The case of Nigeria, the so-called 'giant of Africa' is most instructive. Despite her huge oil wealth Nigeria has remained a consumer economy, unable to use this as an incentive to transform into an industrialized economy and achieve economic self-reliance. It is difficult to imagine that Nigeria imports virtually everything and cannot produce even a pin with all her great potentials.

While the failure to transform into an industrial economy can be explained in terms of a constellation of internal factors tied up with corruption and lack of good governance, the factor of neo-colonialism and imperialism cannot be underestimated. In fact, it is arguable that a certain dialectic subsists between the internal factors and the factor of imperialism and neo-colonialism such that the internal factors themselves are largely epiphenomena of the factor of imperialism, so that unless the neo-colonial structure of the international system is addressed Nigeria as well as other African countries seem destined to be perpetually stuck in the cycle of economic dependence.

At this juncture one may think the solution is easy and wonder why African countries cannot take hold of their destiny in their own hand and break the cycle of economic dependence? Why, for instance, can African countries not process the so-called raw materials themselves and turn them into finished products instead of sending them abroad to be processed only for the finished products to be brought back and sold to them at exorbitant prices? Why for instance can Nigeria not refine her crude oil instead of importing them to the outside world to be refined and then brought back to Nigeria to be sold at exorbitant prices? The right thing to do obviously is to toe the path of self-reliance. But more often than not African countries lack the will power to do so, either because they lack the expertise or the required technology to manage their affairs, so that they are condemned to rely on external assistance; or when they possess the capacity, they are unable to do so because of lack of committed and patriotic leadership, so that we have a situation where the political leadership and corrupt politicians collude with neo-colonial forces and are manipulated into mortgaging the national interest at the altar of personal gratification. As it were the leadership and the political elites are settled while in return they grant access to foreign forces to take control of the economy and exploit it for their own benefits. We see this again and again in virtually all sectors, but the point is that it is simply insufficient to explain this away in terms of corruption without equally accentuating the correlation between corruption and neo-colonialism.[101]

If the goal of neo-colonialism is to instrumentalize the economy of African countries and make it subservient to the global capitalist economy it seems quite convenient to infiltrate the political leadership and the political elite and turn them into instruments for furthering the imperialist agenda of the erstwhile colonial masters. In this context the arrangement is a great service to neo-colonial forces but a great disservice to Africa to the extent that while it undermines the economic autonomy of African countries it gives undue control to external forces.

Interestingly the imbalance we see in the relationship between African countries and the rich countries of the global North with respect to economic globalization is also evident with respect of political globalization. Given that politics and economy are ultimately inseparable it is understandable that the goal of neo-colonialism is to control not only the economy but also the politics of African countries, the idea being that he who controls the politics invariably controls the economy. Without doubt, the post-colonial experience of African countries which is replete with social and political instability eloquently illustrates this point. Interestingly the phenomenon of political instability, like the failure to transform the economy into an industrialized economy, cannot be explained wholly in terms of internal factors. Indeed in many cases the political instability that inflict African countries is engineered from outside and serves ultimately the interests of erstwhile colonial masters who still wish to preserve their influences in their former colony by ensuring that they have in place only the political leadership that can do their bidding.

In this context the situation comes across as a subtle form of 'indirect rule' whereby the erstwhile colonial masters are not physically present on the ground but nonetheless continue to dictate and shape the course of events in their former colonies through their local proxies. So long as they do their bidding, they get the approval of the international community, but when conflict of interest arises then a change of regime is engineered from outside, using internal elements to accomplish the task. I think this motivation virtually explains why military rule persisted in African countries for long, indeed for several decades after independence even when it was clear that such repressive and totalitarian form of leadership was not in the best interest of Africa.[102]

But given that it fulfilled the needs of the erstwhile colonial masters, it was convenient to turn a blind eye to the evil of military incursion into politics and political 
leadership. In retrospect many African countries such as Nigeria, Ghana, Uganda and Burkina Faso that were ruled by military dictators for many decades are counting their losses after a return to civilian democratic rule. But even with the wave of democratization that has blown and is still blowing across the African clime following the end of the cold war, African countries still struggle to realize authentic political autonomy and socio-economic and political stability. Indeed the dawn of democracy has not overcome the influence of neo-colonialism in African politics and economy, as forces of neo-colonialism under the aegis of globalization device new ways of manipulating and controlling the political leadership of African countries through various multinational companies and their subsidiaries.

\section{Conclusions}

What emerges from our account is the extremely complex nature of the African predicament, the fact that it implicates both internal and external factors, so that to gain a full conspectus on the problematic requires not only that both elements be taken into account but more importantly that we also grasp the nature of the dialectic that subsists between both considerations. While there is no denying the fact that Africa needs to assume control over her destiny by defining her priorities and organizing her affairs in terms of her interests rather than alien interests and priorities, the basic truth is that the overall environment of the international system in which she conducts her affair has to be enabling, if she is to succeed in overcoming her predicaments by turning the opportunities of globalization to her advantage.

Without prejudice to the question of her assuming initiative and responsibility for her destiny, the issue of the conduciveness of the environment of the international system is primary and imperative, so that it is simply one-sided and somewhat paternalistic to stress the need for her to take responsibility for her destiny without addressing the imbalance, inequality and injustice that bedevils the internal workings of the international system relative to which she exercises her life and being; for, if the environment is crippling and inherently destabilizing, it remains to be seen how she can possibly exercise her being such as to take hold of her destiny. Invariably it tantamount to expecting the cripple to walk when in fact the condition for the possibility of walking is non-existent.

Yes Africa has to assume personal responsibility for her destiny but she must be allowed to do so. She must be enabled to do so by ensuring that the norms in terms of which the international system operates is just and fair to all stakeholders without one taking undue advantage of the others. Against this backdrop it emerges that one single factor that explains the inability of Africa to break the cycle of dependency is the neo-colonial and seemingly deterministic structure of the international system. Of course, without prejudice to the importance of other factors, the point is that the cycle can hardly be broken without addressing the fundamental imbalance that informs the relationship between Africa and the rich nations of the global North.

The neo-colonial trappings of globalization no doubt represent the dark side of globalization. But it also explains why despite the immense benefits that Africa seemingly derives from globalization, globalization has paradoxically been unable to pull Africa out of poverty but witnesses her further descent into the abyss of poverty.[103] What is clear therefore is that while Africa needs to re-organize herself and begin to engage the global world in terms of her priorities and interests, Africa needs to be set free from the forces of neo-colonialism; there is need to overcome the neo-colonial trappings of globalization in order for globalization to serve the genuine interest of Africa and become an instrument of her development. The journey of Africa from poverty to wealth must begin from here; the journey from inferiority complex to self-belief must begin with a redress of the imbalance that plagues the international system. Was this to happen then there will be real hope for Africa as Africa is empowered and enabled to overcome her predicament.[104]

\section{REFERENCES}

[1] Cf. Thiong'o, Ngugi wa. "African Identities: Pan Africanism in the Era of Globalization and Capitalist Fundamentalilsm" in Macalester International, 2004: Volume 14, Article 9, pp. 22-42

[2] Ibid.

[3] Ibid.

[4] See Baylis, J. Smith, S. and Owens, P. The Globalization of World Politics: An Introduction to International Relations, $4^{\text {th }}$ Edition .Oxford: Oxford University Press, 2008, pp. 16-30. See also "Globalization" Wikipedia, the Free Encyclopedia, retrieved on $5^{\text {th }}$ September 2016; Beck, U. What is Globalization? (Cambridge: Polity Press, 1999) and M. Walters, Globalization London: Routledge, 1995

[5] Cf. Steger, Manfred B. Globalization: A Very Short Introduction Oxford: Oxford University Press, 2013; See also Ibrahim, A. "The Impact of Globalization on Africa" International Journal of Humanities and Social Science, Volume 3, No 5, 2013, pp. 85-93

[6] See Baylis, J, Smith, Steve and Owen, P. The Globalization of World Politics: An Introduction to International Relations, $4^{\text {th }}$ Edition, pp. 1-14. Cf. Ilodigwe, Damian, Bradley and the Problematic Status of Metaphysics Newcastle: Cambridge Publishing, 2006, Chapter 1

[7] Cf. Rouke, John T, International Politics on the Global Stage McGraw Hill, 2003, pp. 1-26

[8] Ibid. 
[9] Cf. Ilodigwe, Damian. Bradley and the Problematic Status of Metaphysics, pp. 1-30

[10] See "Globalization" Wikipedia, the free Encyclopedia Retrieved $5^{\text {th }}$ September 2016 downloaded $5^{\text {th }}$ September 2016. See also Ullan de la Rosa, Francis Xavier. "Trans-African Identity: Cultural Globalization and the Role of the Symbolic-aesthetic dimension in the present identity construction processes" in African Journal of History and Culture Vol. 3(8), pp. 2011:128-134

[11] See Steger, Manfred B. Globalization: A Very Short Introduction, pp. 17-37. See also Igbafen, Monday L. "Africa in a Globalised World", in Martin F. Asiegbu and Joseph A. Agbakoba, Philosophy and Praxis in Africa (Ibadan: Hope Publications, 2006), pp. 287-300

[12] See Steger, Globalization: A Very Short Introduction, pp. 17-37, See also Odimegwu, Ferd-Harris. "Globalization and African Identity" in Martin F. Asiegbu and Joseph A. Agbakoba, Philosophy and Praxis in Africa (Ibadan: Hope Publications, 2006), pp. pp. 309-328

[13] See "Globalization" Wikipedia, the free Encyclopedia Retrieved on $5^{\text {th }}$ September 2016

[14] Hurrel, A. and Wood, N. "Globalization and Inequality" in Journal of International Studies, Volume 24, No 3, 1995.

[15] Ibrahim, A. "The Impact of Globalization on Africa" International Journal of Humanities and Social Science, Volume 3, No 5, 2013, pp. 85-93; See also Odimegwu, Ferd-Harris. "Globalization and African Identity" in Martin F. Asiegbu and Joseph A. Agbakoba, Philosophy and Praxis in Africa (Ibadan: Hope Publications, 2006), pp. pp. 309-328

[16] Cf. Steger, Globalization: A Very Short Introduction, pp. 8-12. See also Baylis, J. Smith, S and Owens, P. The Globalization of World Politics: An Introduction to International Relations, $4^{\text {th }}$ Edition, pp. 1-14

[17] See Rouke, J. T. International Politics on the World Stage, pp. 2-22

[18] See "Globalization", Wikipedia, the Free Encyclopedia, retrieved on $5^{\text {th }}$ September 2015

[19] See Rouke, J. T. International Politics on the World Stage, See Steger, Globalization: A Very Short Introduction, pp. 12-17 and James, Paul; Steger, Manfred B. (2014). "A Genealogy of globalization: The career of a concept". $\begin{array}{llll}\text { Globalizations. } & 11 & \text { (4): } & 417-434 .\end{array}$ doi:10.1080/14747731.2014.951186.

[20] See Kanu Anthony, African Identity and the Emergence of Globalization, American International Journal of Contemporary Research Vol. 3 No. 6; June 2013, pp. 34-42

[21] Steger, Manfred B. Globalization: A Very Short Introduction, pp. 17-37

[22] Ibid.

[23] See Steger, Manfred B. Globalization: A Very Short Introduction, pp. 17-36

[24] See also "Globalization", Wikipedia, the free Encyclopedia, retrieved on $5^{\text {th }}$ September 2016

[25] Steger, Manfred B. Globalization: A Very Short
Introduction, pp. 20-23

[26] See Spero, Joan Edelman and Hart, A., The Politics of Economic Relations, 2nd Edition London: George Allen and Unwin, 1981), pp. 137-246

[27] Ibid.

[28] Ibid.

[29] Ibid.

[30] Mcmahon, Robert J. Cold War: A Very Short Introduction Oxford: Oxford University Press, 2014

[31] Rouke, John T. International Politics on the World Stage, pp. Chapters 14 and 15

[32] Spero, Joan Edelman and Hart, The Politics of Economic Relations, $7^{\text {th }}$ Edition London: George Allen and Unwin, 1981), pp. 137-246

[33] See Steger, Globalization: A Very Short Introduction, pp. 58-70. See also "Globalization" Wikipedia, the Free Encyclopedia, retrieved on $5^{\text {th }}$ September 2016

[34] Rouke, John T. International Politics on the World Stage, pp. 2-21; See also Hans Morgenthau, Politics Among Nations: The Struggle for Power and Peace New York: Alfred A. Knopf, 1948

[35] See also Robert J. Art and Robert Jervis, International Politics: Enduring Concepts and Contemporary Issues, $4^{\text {th }}$ Edition New York: Harper Collins College Publishers, 1996, pp. 1-6

[36] Ibid.

[37] Ibid.

[38] Ibid. See also Abdul Aziz Said, Charles O. Lerche and Charles O. Lerche III, Concepts of International Politics in Global Perspective, $4^{\text {th }}$ Edition (New Jersey, Englewood Cliffs. Prentice-Hall, 1996), pp. 68-74.

[39] See Steger, Globalization: A Very Short Introduction, pp. $58-70$

[40] Perhaps the most pivotal of these International Organizations is the United Nations whose overall aim is maintaining peace among the Nations. See Roberts, Adams and Kingsbury, Benedict (eds), United Nations: Divided World: The UN Role in International Relations, $2^{\text {nd }}$ edition, 1988. See also John W. Young and John Kent, International Relations Since 1945: A Global History (Oxford: Oxford University Press, 2004), pp. 1-15.

[41] Cf. Steger, Globalization: A Very Short Introduction, 58-70

[42] McMahon, Cold War: A Very Short Introduction, Chapter 2

[43] Cf. Rouke, John T. International Politics on the World Stage, 27-52

[44] See Steger, Globalization: A Very Short Introduction, pp. 58-70

[45] Ibid.

[46] See "Globalization", The Free Encyclopedia, retrieved on $5^{\text {th }}$ September, 2016

[47] Ibid. 
[48] Ibid.

[49] See Steger, Globalization: A Very Short Introduction, pp. $71-83$

[50] Cf. "Globalization" Wikipedia, The Free Encyclopedia, retrieved on $5^{\text {th }}$ September 2016

[51] Cf. Steger, Globalization: A Very Short Introduction, pp. 84-97

[52] Ibid.

[53] See Rouke, John T. International Politics on the World Stage, pp. 548-568

[54] Cf. Steger, Manfred B. Globalization: A Very Short Introduction, pp. 84-97

[55] Ibid, pp. 1-36

[56] Ibid.

[57] Ibid.

[58] Cf. "Globalization" Wikipedia, The Free Encyclopedia, retrieved on $5^{\text {th }}$ September 2016; see also Odimegwu, Ferd-Harris. "Globalization and African Identity" in M. F. Asiegbu and J. A. Agbakoba (eds), Philosophy and Praxis in Africa Ibadan: Hope Publication, 2006, pp. 309-328

[59] Rouke, John T. International Politics on the World Stage, Ninth Edition McGraw Hill, 2002, pp. 32-39. See also "Globalization" Wikipedia, the Free Encyclopedia, retrieved on $5^{\text {th }}$ September 2016

[60] Ibid.

[61] See Laleye, Solomon "A Philosophical Picturing of Africa in the Globalization Project", in Journal of Law, Policy and Globalization, Vol. 23, 2014: pp. 109-115. See also Odimegwu, Ferd-Harris "Globalization and African Identity" in M. F. Asiegbu and J. A. Agbakoba (eds), Philosophy and Praxis in Africa Ibadan: Hope Publication, 2006, pp. 309-328

[62] Cf. Igbafen, Monday L. "Africa in a Globalized World" in M. F. Asiegbu and J A. Agbakoba (eds) Philosophy and Praxis in Africa, pp. 287-307

[63] Cf.Thiong'o, Ngugi wa. "African Identities: Pan Africanism in the Era of Globalization and Capitalist Fundamentalilsm" in Macalester International, Volume 14, Article 9, pp. 22-42. See also Solomon A Laleye, "A Philosophical Picturing of Africa in the Globalization Project" Journal of Law, Policy and Globalization, Vol. 23, 2014: 109-115

[64] Ibid.

[65] Cf.Thiong'o, Ngugi wa. "African Identities: pan Africanism in the Era of Globalization and Capitalist Fundamentalilsm" in Macalester International, Volume 14, Article 9, pp. 22-42

[66] Cf. Odimegwu, Ferd- Harris "Globalization and African Identity" in M. F. Asiegbu and J. A. Agbakoba (eds), Philosophy and Praxis in Africa Ibadan: Hope Publication, 2006, pp. 309-328

[67] See Laleye, Solomon. "A Philosophical Picturing of Africa in the Globalization Project”, in Journal of Law, Policy and
Globalization, Vol. 23, 2014: pp. 109-115.

[68] Cf. Chukwujekwu, Steve. "Globalization and the Developing World" in Ferd-Harris Odimegwu, "Globalization and African Identity" in M. F. Asiegbu and J. A. Agbakoba (eds), Philosophy and Praxis in Africa Ibadan: Hope Publication, 2006, pp. 309-328

[69] Cf. Thiong'o, Ngigi wa. "African Identities: pan Africanism in the Era of Globalization and Capitalist Fundamentalilsm" in Macalester International, Volume 14, Article 9, pp. $22-42$

[70] Cf. John T. Rouke, International Politics on the World Stage, pp. Chapter 15. See also Cf. Steve Chukwujekwu, "Globalization and the Developing World" in Ferd-Harris Odimegwu, "Globalization and African Identity" in M. F. Asiegbu and J. A. Agbakoba (eds), Philosophy and Praxis in Africa (Ibadan: Hope Publication, 2006), pp. 309-328

[71] Ibid

[72] Cf. Thiong'o, Ngugi wa. "African Identities: pan Africanism in the Era of Globalization and Capitalist Fundamentalilsm" in Macalester International, Volume 14, Article 9, pp. 22-42.

[73] Ibid.

[74] See Laleye, Solomon. "A Philosophical Picturing of Africa in the Globalization Project", in Journal of Law, Policy and Globalization, Vol 23, 2014: pp. 109-115.

[75] Cf. Thiong'o, Ngugi wa. "African Identities: pan Africanism in the Era of Globalization and Capitalist Fundamentalilsm" in Macalester International, Volume 14, Article 9, pp. 22-42

[76] This crisis is evident in virtually every ramification of African life and politics for being unable to achieve self-reliance the tendency then is to depend on the other. The embarrassment that can result when such dependence is politicized and turned into a political tool of negotiation is well illustrated the with the recent case of Nigeria's arms deal predicament in the face of the Boko Haram insurgency for it turned out that for various reasons all the nations Nigeria is used to depending on simply refused to sell arms to Nigeria, leaving Nigeria not only vulnerable but unable to counter the Boko Haram insurgency. See News Source nationalmirroronline.net posted on December 22, 2014.

[77] Ibid.

[78] See Laleye, Solomon. "A Philosophical Picturing of Africa in the Globalization Project", in Journal of Law, Policy and Globalization, Vol 23, 2014: pp. 109-115

[79] Cf. Rouke, John T. International Politics on the World Stage, pp. 429-460

[80] See Laleye, Solomon. "A Philosophical Picturing of Africa in the Globalization Project", in Journal of Law, Policy and Globalization, Vol 23, 2014: pp. 109-115

[81] Cf. Rouke, John T. International Politics on the World Stage, pp. $28-50$

[82] Cf. Thiong'o, Ngugi wa. "African Identities: pan Africanism in the Era of Globalization and Capitalist Fundamentalilsm" in Macalester International, Volume 14, Article 9, pp. 22-42 
[83] Cf. Thiong'o, Ngugi wa. "African Identities: pan Africanism in the Era of Globalization and Capitalist Fundamentalilsm" in Macalester International, Volume 14, Article 9, pp. 22-42

[84] Cf. Rouke, John T. International Politics on the World Stage, Chapter 15

[85] Rodney, Walter. How Europe Under-developed Africa, Tanzania: Tanzania Publishing House, 1972

[86] Cf. Thiong'o, Ngugi wa. "African Identities: pan Africanism in the Era of Globalization and Capitalist Fundamentalilsm" in Macalester International, Volume 14, Article 9, pp. 22-42

[87] Fanon, Frantz. The Wretched of the Earth. Translated by Charles Lam Markmann London: MacGibbon and Kee, 1968.

[88] Cf. Thiong'o, Ngugi wa. “African Identities: pan Africanism in the Era of Globalization and Capitalist Fundamentalilsm" in Macalester International, Volume 14, Article 9, pp. 22-42

[89] Fanon, Frantz. The Wretched of the Earth, translated by Constance Farrignton New York: Grove Press, 1963

[90] Cf. Thiong'o, Ngugi wa. “African Identities: pan Africanism in the Era of Globalization and Capitalist Fundamentalilsm" in Macalester International, Volume 14, Article 9, pp. 22-42

[91] Cf. Rouke, John T. International Politics on the World Stage, pp. 430-442

[92] This point is well illustrated by the consistent failure in sports administration in Nigeria. It is unthinkable that people will work without motivation and still fail to be appreciated when they excel in such debilitating situation. Yet that has been the consistent story of Nigeria sport as the just concluded Rio Olympics illustrates with the sort of treatment meted out to the Dream Team what emerged with Bronze medal, the only medal Nigeria could boast of in unbelievably difficult circumstances. See "Siasia Quits, Says Nigeria Football System is disrespectful", Guardian Newspaper, August 28, 2016
[93] Cf. John T. Rouke, International Politics on the World Stage, pp. 27-58

[94] Cf. Thiong'o, Ngugi wa. "African Identities: pan Africanism in the Era of Globalization and Capitalist Fundamentalilsm" in Macalester International, Volume 14, Article 9, pp. 22-42

[95] Cf. Somerville, Keith. "Africa After the Cold War: Frozen out or Frozen in Time?" in The Third World Beyond the Cold War: Continuity and Change edited by Louis Fawcett and Yezid Sayigh (Oxford University Press,2000), pp. $134-168$

[96] Cf. Rouke, John T. International Politics on the World Stage, pp. 401-427

[97] Cf. Thiong'o, Ngugi wa. "African Identities: pan Africanism in the Era of Globalization and Capitalist Fundamentalilsm" in Macalester International, Volume 14, Article 9, pp. 22-42

[98] See Krasner, Stephen D. "Power Vs Wealth in North and South Economic Relations" in Robert J. Art and Robert Jervis, International Politics (New York: HarperCollinsCollegePublishers, 1996), pp. 299-318

[99] Cf. Sen, Gautam. "Developing States and the End of the Cold War: Liberalization, Globalization and their Consequences" in The Third World Beyond the Cold War: Continuity and Change edited by Louis Fawcett and Yezid Sayigh (Oxford University Press, 2000), pp. 56-77

[100] Cf. Ilodigwe, Damian. "Communication and Diplomacy as an Instrument of Good Governance and Sustainable Economic Development" in Journal of Power, Politics and Governance, 2017: 5: 1-28

[101] Ibid.

[102] Ibid.

[103] Cf. Rouke, John T. International Politics on the World Stage, pp. $401-427$

[104] Ibid. 